\title{
Influence of modern land cover on the climate of the United States
}

\author{
Noah S. Diffenbaugh
}

Received: 25 May 2008/Accepted: 23 March 2009/Published online: 10 April 2009

(C) The Author(s) 2009. This article is published with open access at Springerlink.com

\begin{abstract}
I have used a high-resolution nested climate modeling system to test the sensitivity of regional and local climate to the modern non-urban land cover distribution of the continental United States. The dominant climate response is cooling of surface air temperatures, particularly during the warm-season. Areas of statistically significant cooling include areas of the Great Plains where crop/mixed farming has replaced short grass, areas of the Midwest and southern Texas where crop/mixed farming has replaced interrupted forest, and areas of the western United States containing irrigated crops. This statistically significant warm-season cooling is driven by changes in both surface moisture balance and surface albedo, with changes in surface moisture balance dominating in the Great Plains and western United States, changes in surface albedo dominating in the Midwest, and both effects contributing to warm-season cooling over southern Texas. The simulated changes in surface moisture and energy fluxes also influence the warm-season atmospheric dynamics, creating greater moisture availability in the lower atmosphere and enhanced uplift aloft, consistent with the enhanced warmseason precipitation seen in the simulation with modern land cover. The local and regional climate response is of a similar magnitude to that projected for future greenhouse gas concentrations, suggesting that the climatic effects of land cover change should be carefully considered when crafting policies for regulating land use and for managing anthropogenic forcing of the climate system.
\end{abstract}

\section{N. S. Diffenbaugh $(\bowtie)$}

Department of Earth and Atmospheric Sciences,

Purdue Climate Change Research Center, Purdue University, 550 Stadium Mall Drive, West Lafayette, IN 47907-2051, USA

e-mail: diffenbaugh@purdue.edu

\section{Introduction}

It is now well established that land cover influences surface climate, both through biophysical interactions that affect surface energy balance and through biogeochemical interactions that affect the carbon cycle (Pielke et al. 2002). Biophysical influences are exerted by both human-dominated and "natural" landscapes. For instance, the presence of urban areas causes local heating (e.g., Brazel et al. 2007) and can even alter the path of individual thunderstorms (e.g., Changnon 2001). Likewise, deforestation has been shown to explain observed regional drying in both the tropics (Werth and Avissar 2002) and extratropics (Pitman et al. 2004). It has also been argued that agricultural expansion contributed to northern hemisphere cooling prior to substantial increases in greenhouse gas concentrations (e.g., Govindasamy et al. 2001). Further, even before widespread human perturbations of the landscape, land cover change played a key role in shaping regional paleoclimates, with biophysical land cover effects especially important to regional climate sensitivity (e.g., Diffenbaugh and Sloan 2002; Foley et al. 1994; Wyputta and McAvaney 2001).

Here I examine the influence of modern land cover on climate in the continental United States. The mean surface temperature of the earth has increased over the past 160 years, with the steepest warming occurring over the last quarter century (IPCC 2007). This warming has occurred over both land and ocean, with elevated greenhouse gas concentrations being the most likely culprit (IPCC 2007). However, although a number of first-order discrepancies in the instrumental data have been reconciled (e.g., Mears and Wentz 2005; Santer et al. 2008; Sherwood et al. 2005), there remains uncertainty as to how other climate forcings have acted to modify the effects of rising greenhouse gas concentrations, particularly at local and 
regional scales. For instance, it has been argued that agricultural areas have warmed the surface by increasing the heat capacity of the soil and vegetation (Christy et al. 2006; Kalnay and Cai 2003). Conversely, climate model experiments suggest that agricultural areas have cooled the surface (e.g., Feddema et al. 2005a; Govindasamy et al. 2001; Kueppers et al. 2007; Lobell et al. 2006b), leading to the hypothesis that widespread irrigation has "masked" the global warming signal (Kueppers et al. 2007).

In addition to influences on past climate, changes in land cover resulting from both direct human modification and biogeographic change could have substantial impact on surface climate in the coming decades (e.g., Diffenbaugh 2005a, b; Feddema et al. 2005b; Jackson et al. 2005). In fact, as scientists and policy makers grapple with ways to mitigate potential greenhouse gas-induced changes in climate, climate policy is itself emerging as a potential driver of land cover change (e.g., Fargione et al. 2008; Jackson et al. 2005; Searchinger et al. 2008). We are therefore faced with the possibility that biofuel and sequestration markets (and mandates) could influence climate not only through changes in greenhouse gas concentrations, but also through changes in surface energy and water budgets (e.g., Bala et al. 2007; Betts 2000; Jackson et al. 2005).

Quantifying the influence of biophysical land cover effects is thus critical both for understanding observed changes in the climate system during the recent period of intense human perturbation, and for understanding how the climate system may change in the future. Further, because the response of regional and local climate to land cover forcing could be different than the response to global greenhouse gas forcing (e.g., Diffenbaugh 2005a), and because the influence of land cover is likely to be stronger at local and regional scales than at the global scale (e.g., IPCC 2007), it is imperative that this quantification of biophysical effects be made at fine spatial scales over large continental areas.

\section{Models and methods}

I have employed the ICTP RegCM3 nested climate model (Pal et al. 2007). RegCM3 successfully captures the climatological patterns of temperature and precipitation over the continental United States (Diffenbaugh et al. 2006). The domain used here follows that of (Diffenbaugh et al. 2005), which covers the full continental United States and surrounding areas with $25 \mathrm{~km}$ horizontal grid spacing. The domain has 145 points in the latitude direction and 220 points in the longitude direction, with 18 levels in the vertical. For this grid, the model uses a 75-s time-step.

RegCM3 uses the hydrostatic dynamical core from MM5 (Grell et al. 1994), the radiative transfer package from CCM3 (Kiehl et al. 1996), and the nonlocal countergradient boundary layer scheme of Holtslag et al. (1990). Large-scale ("non-convective") precipitation is parameterized using the SUBEX physics scheme (Pal et al. 2000). In the simulations reported here, cumulus convection is parameterized using the Grell scheme (Grell 1993), with the Fritsch and Chappell closure assumption (Fritsch and Chappell 1980).

RegCM3 uses the Biosphere-Atmosphere Transfer Scheme (BATS 1e) (Dickinson et al. 1993) to calculate fluxes of energy, momentum and moisture between the land surface and the atmosphere. BATS has one vegetation layer and three soil layers. The vegetation and soil properties are parameterized based on a single land cover designation at each grid point. The phenological variables are prescribed for each land cover type based on fixed parameters, such as minimum leaf area index (LAI), maximum LAI, and maximum fractional vegetation cover, along with the seasonal progression of temperature. The BATS land cover types include parameterizations for both irrigated crop and crop/mixed farming areas. In the irrigated crop areas, root zone soil moisture is set to field capacity throughout the year.

I have tested the response of climate in the United States to land cover change using two different land cover distributions (Fig. 1). The modern land cover is defined by the Global Land Cover Characteristics (GLCC) data (Loveland et al. 2000). This land cover distribution was originally defined at $1 \mathrm{~km}$ horizontal resolution from remotely sensed Advanced Very High Resolution Radiometer (AVHRR) measurements. The potential vegetation distribution of the United States is defined by Ramankutty and Foley (1999) (RF). This land cover distribution was also derived from the $1 \mathrm{~km}$ AVHRR data, with crop areas replaced by the potential vegetation designations of Haxeltine and Prentice (1996) on a 5-min geographical grid.

In the experiments reported here, both datasets were gridded to the $25 \mathrm{~km} \mathrm{RegCM} 3$ grid (Fig. 1). The most prominent difference between the two datasets is the presence of crop types in the GLCC dataset. Large areas of crop/mixed farming are replaced in the RF dataset primarily by short grass in the Great Plains, interrupted forest in the Midwest and southern Texas, and evergreen needleaf trees in the Southeast. Smaller areas of irrigated crop occur in the western United States and are replaced in the RF dataset primarily by various mixtures of interrupted forest, short grass, evergreen shrubs, and semidesert.

I have conducted two climate model integrations covering the period 1982-2002, with the NCEP-DOE Reanalysis Product (Kanamitsu et al. 2002) providing large-scale boundary conditions for both integrations. One integration (GLCC) uses the modern non-urban land cover distribution from the GLCC database (Fig. 1a). The other 
Fig. 1 Non-urban land cover distribution in the continental United States. a Modern distribution derived from Loveland et al. (2000). b Potential vegetation distribution derived from Ramankutty and Foley (1999). b Shows potential vegetation in the areas where land cover is different between the two distributions. Areas of (b) that are white were not changed between the two simulations

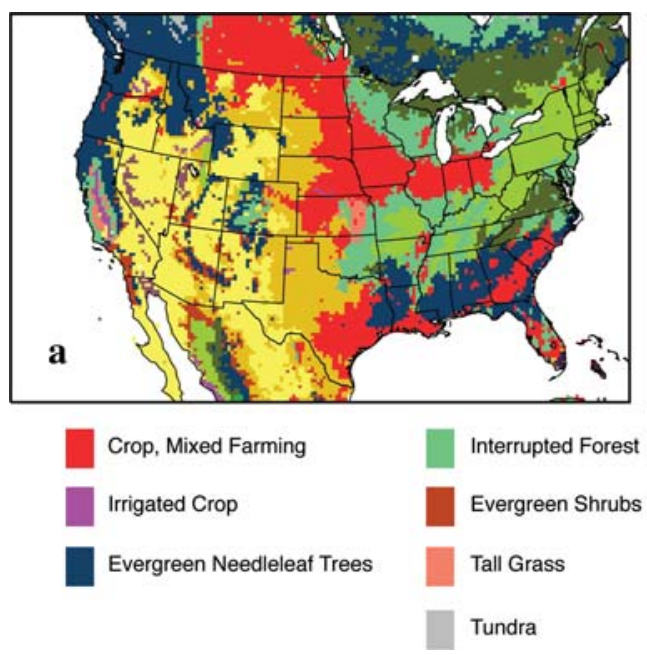

integration (RF) uses the potential vegetation distribution of (Ramankutty and Foley 1999) (Fig. 1b). The land cover types are applied as the bottom boundary condition in RegCM3 with the distribution shown in Fig. 1, using the parameterizations in BATS. Annually-varying greenhouse gas concentrations are prescribed following Schlesinger and Malyshev (2001).

Previous work shows that land surface schemes can require multiple years to equilibrate (Yang et al. 1995). In both integrations, the first 6 years are discarded to account for climate model equilibration, leaving the 15 years from 1988 through 2002 for climate model analysis. I have tested the statistical significance of the mean monthly temperature and precipitation changes using Student's $t$ test.

Finally, I have used three datasets to identify recent temperature changes in the United States: the WillmottMatsuura global terrestrial air temperature timeseries (Willmott and Matsuura 2001) (1988-1999), the Climate Research Unit TS 2.0 timeseries (Mitchell and Jones 2005) (1988-2000), and the North American Regional Reanalysis product (Mesinger et al. 2006) (1988-2002).

\section{Results}

\subsection{Seasonal means}

The GLCC land cover distribution results in annual cooling of mean surface air temperature, with the continental United States cooling by $0.19 \mathrm{~K}$, crop and mixed farming areas cooling by $0.36 \mathrm{~K}$, and irrigated crop areas cooling by $1.52 \mathrm{~K}$ (Table 1 ). Temperature change (GLCC minus $\mathrm{RF}$ ) is relatively small in December-January-February (DJF), with peak cooling of less than $0.8^{\circ} \mathrm{C}$ (Fig. 2). Changes in DJF daily maximum and minimum surface air
Table 1 Means (K) and trends (K/decade) of annual surface air temperature in the RF and GLCC simulations (1988-2002)

\begin{tabular}{lrccc}
\hline & US & $\begin{array}{l}\text { Areas changed } \\
\text { from crop/mixed } \\
\text { farm }\end{array}$ & $\begin{array}{l}\text { Areas changed } \\
\text { from irrigated } \\
\text { crop }\end{array}$ & $\begin{array}{l}\text { Non-crop } \\
\text { areas }\end{array}$ \\
\hline RF trend & 0.21 & 0.12 & 0.15 & 0.21 \\
GLCC trend & 0.16 & -0.01 & 0.11 & 0.16 \\
RF mean & 284.62 & 285.93 & 288.33 & 284.25 \\
GLCC mean & 284.43 & 285.57 & 286.81 & 284.12 \\
\hline
\end{tabular}

The observational trends over the US domain are 0.43 (Climate Research Unit; 1988-2002), 0.52 (Willmott-Matsuura; 1988-1999), 0.30 (North American Regional Reanalysis; 1988-2002)

"Non-crop areas" are those grid points not designated as crop/mixed farming or irrigated crop in the GLCC simulation

temperature are generally similar to changes in DJF mean surface air temperature. However, the GLCC land cover results in slight warming of minimum temperature of up to $1.2^{\circ} \mathrm{C}$ over areas of the western and central United States. Changes in DJF precipitation are negligible.

Changes (GLCC minus RF) in March-April-May (MAM) surface air temperature are negative throughout most of the United States, with the largest decreases of at least $-3^{\circ} \mathrm{C}$ occurring over California and the eastern Gulf of California (Fig. 3). The pattern of changes in MAM daily maximum surface air temperature is very similar to that of mean MAM surface air temperature, although the magnitude of change is approximately twice as large (including peak changes of greater than $-6^{\circ} \mathrm{C}$ ). Conversely, changes in MAM daily minimum surface air temperature are much smaller, with increases of up to $1.8^{\circ} \mathrm{C}$ over areas of the western United States. Changes in MAM total precipitation are positive over much of the central and southeastern United States, with increases of up to $1.8 \mathrm{~mm} /$ day over southern Texas and Florida. Decreases 
Fig. 2 Change in winter (DJF) surface moisture balance associated with conversion of land cover. Changes are calculated as GLCC minus RF. a Total precipitation ( $\mathrm{mm} /$ day). b Net longwave radiation $\left(\mathrm{W} / \mathrm{m}^{2}\right)$. c Surface evapotranspiration ( $\mathrm{mm} /$ day). d Surface sensible heat flux $\left(\mathrm{W} / \mathrm{m}^{2}\right)$. e Surface soil moisture $(\mathrm{mm})$. f Net shortwave radiation $\left(\mathrm{W} / \mathrm{m}^{2}\right)$. g Daily maximum surface air temperature $\left({ }^{\circ} \mathrm{C}\right)$. h Daily minimum surface air temperature $\left({ }^{\circ} \mathrm{C}\right)$. i Surface air temperature $\left({ }^{\circ} \mathrm{C}\right)$
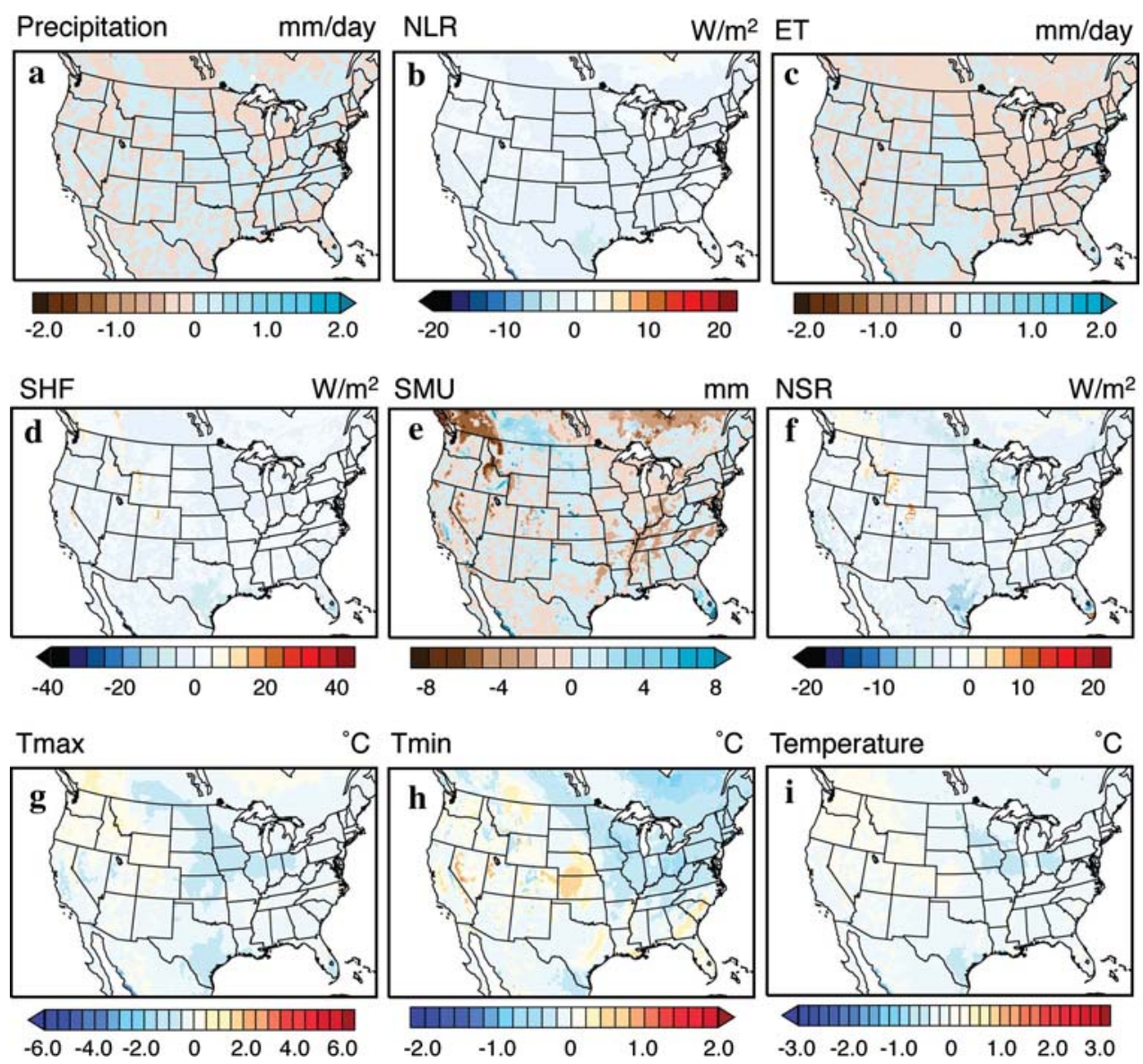

in MAM total precipitation of up to $0.8 \mathrm{~mm} /$ day occur over much of the eastern United States.

Changes (GLCC minus RF) in JJA surface air temperature are negative over much of the continental United States, with peak decreases of greater than $-3^{\circ} \mathrm{C}$ over the central United States and parts of the western United States (Fig. 4). Changes in JJA daily maximum surface air temperature show a similar pattern, but with substantially larger magnitude, including peak decreases of greater than $-6^{\circ} \mathrm{C}$. Alternatively, decreases in JJA daily minimum surface air temperature are much smaller than decreases in JJA mean surface air temperature. JJA total precipitation increases over much of the central and southeastern United States, with peak increases of greater than $2 \mathrm{~mm} /$ day occurring over southern Florida, southern Texas, and parts of the Mountain West. Conversely, decreases in JJA total precipitation of up to $-1.2 \mathrm{~mm} /$ day occur over the northeastern United States.

Changes (GLCC minus RF) in SON surface air temperature, daily maximum surface air temperature, and daily minimum surface air temperature are negative throughout most of the domain (Fig. 5). Peak decreases in SON surface air temperature (greater than $-3^{\circ} \mathrm{C}$ ) and daily maximum air temperature (greater than $-6^{\circ} \mathrm{C}$ ) occur over the Central Valley of California, while peak increases in daily minimum air temperature of up to $1.8^{\circ} \mathrm{C}$ occur over parts of Nevada, Utah, and California. Changes in SON precipitation are negligible.

When the results are screened for statistical significance ( $95 \%$ confidence level), the precipitation changes are found to be almost universally not significant, even at the mean monthly timescale (Fig. 6). The largest areas of significant temperature change occur in mean monthly surface air temperature and mean daily maximum temperature over the northern Great Plains, the Midwest, and southern Texas. Over the Great Plains, where crop/mixed farming was replaced by short grass (Fig. 1), the GLCC simulation shows increased warm-season surface soil moisture (up to $5 \mathrm{~mm}$ ) and evapotranspiration (up to $1.2 \mathrm{~mm} /$ day), along with decreased net longwave flux (up to $-12.5 \mathrm{~W} / \mathrm{m}^{2}$ ) and sensible heat flux (up to $-30 \mathrm{~W} / \mathrm{m}^{2}$ ) at the surface. Over the Midwest (Indiana, Illinois and Iowa), where crops were replaced by interrupted forest, the GLCC simulation shows decreased warm-season surface net shortwave flux (up to and exceeding $-20 \mathrm{~W} / \mathrm{m}^{2}$ ) and sensible heat flux (up to $30 \mathrm{~W} / \mathrm{m}^{2}$ ). Over southern Texas, where crops were also replaced by interrupted forest, the GLCC simulation shows decreased warm-season surface net shortwave flux (up to 
Fig. 3 As in Fig. 2, but for spring (MAM)

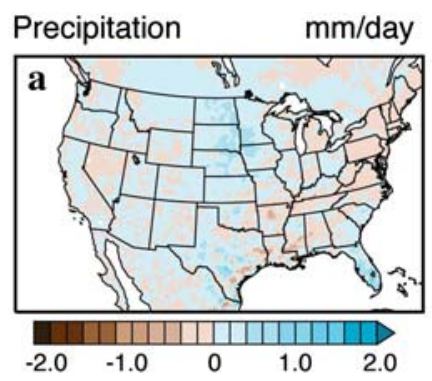

NLR

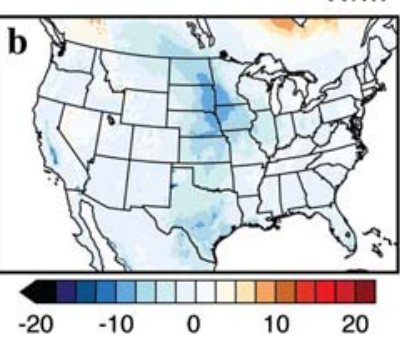

$W / m^{2} E T$
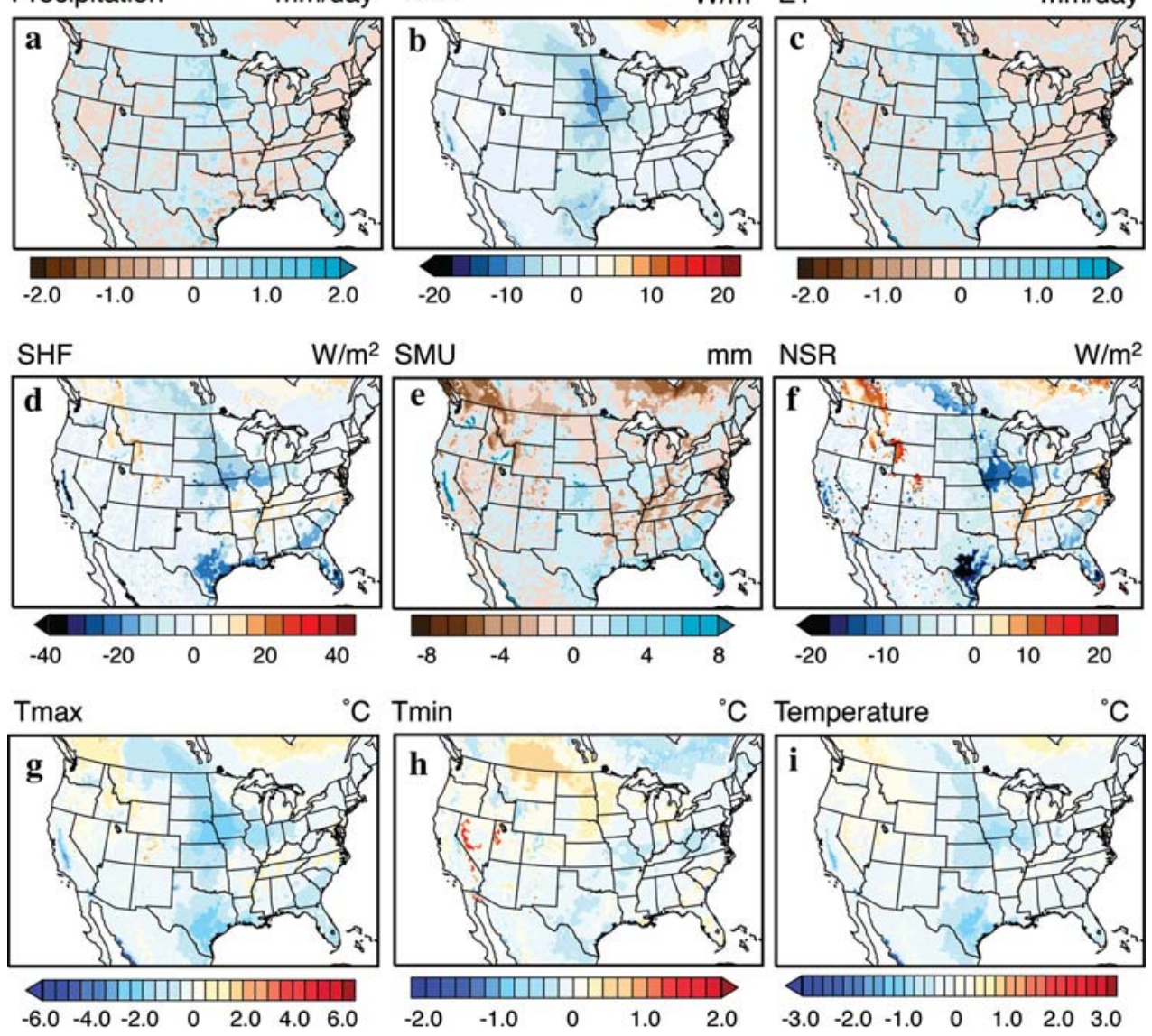

3.2 Late twentieth century trends

and exceeding $-20 \mathrm{~W} / \mathrm{m}^{2}$ ) and sensible heat flux (up to $-40 \mathrm{~W} / \mathrm{m}^{2}$ and increased warm-season surface soil moisture (up to $5 \mathrm{~mm}$ ) and evapotranspiration (up to $1.2 \mathrm{~mm} /$ day).

Changes in mean monthly surface air temperature and daily maximum temperature are also statistically significant in the warm-season over areas of the western United States designated as irrigated crop in the GLCC simulation (Figs. 1, 6). (The changes are statistically significant over the irrigated areas of the Central Valley of California through October and November, respectively.) In these areas, the GLCC simulation shows increased warm-season surface soil moisture $(>8 \mathrm{~mm})$ and evapotranspiration (up to $>2.0 \mathrm{~mm} /$ day), along with decreased surface net longwave flux $\left(>-20 \mathrm{~W} / \mathrm{m}^{2}\right)$ and sensible heat flux $\left(>-40 \mathrm{~W} / \mathrm{m}^{2}\right)$. Changes in mean daily minimum temperature are statistically significant over areas of the western United States from March through October (Fig. 6). These areas exhibit warming of daily minimum temperatures in the GLCC simulation where desert was converted to semidesert, decreasing net shortwave flux by up to $-12.5 \mathrm{~W} / \mathrm{m}^{2}$, while decreasing surface soil moisture by up to $-3 \mathrm{~mm}$ and evapotranspiration by up to $-0.8 \mathrm{~mm} /$ day.
The three observationally-based datasets each show a positive surface air temperature trend over the late twentieth century period (Climate Research Unit $=0.43 \mathrm{~K} /$ decade, Willmott-Matsuura $=0.52 \mathrm{~K} /$ decade, North American Regional Reanalysis $=0.30 \mathrm{~K} /$ decade; Table 1 ). Both climate model simulations show weaker positive trends over the United States, with the RF simulation showing a stronger trend $(0.21 \mathrm{~K} /$ decade $)$ than the GLCC simulation (0.16 K/decade) (Table 1$)$. In addition, when analyzing only those grid points for which land cover is different between the modern and preindustrial datasets (Fig. 1b), the RF simulation shows more strongly positive trends than the GLCC simulation for areas changed to crop/mixed farming ( 0.12 and $-0.01 \mathrm{~K} /$ decade, respectively), areas changed to irrigated crop ( 0.15 and $0.11 \mathrm{~K} /$ decade, respectively), and areas not designated as either crop type in the GLCC simulation ( 0.21 and $0.16 \mathrm{~K} /$ decade, respectively).

The three observational datasets also show similar time evolution of United States surface air temperature anomalies over the late twentieth century (expressed as annual differences from the respective long-term mean of each 
Fig. 4 As in Fig. 2, but for summer (JJA)
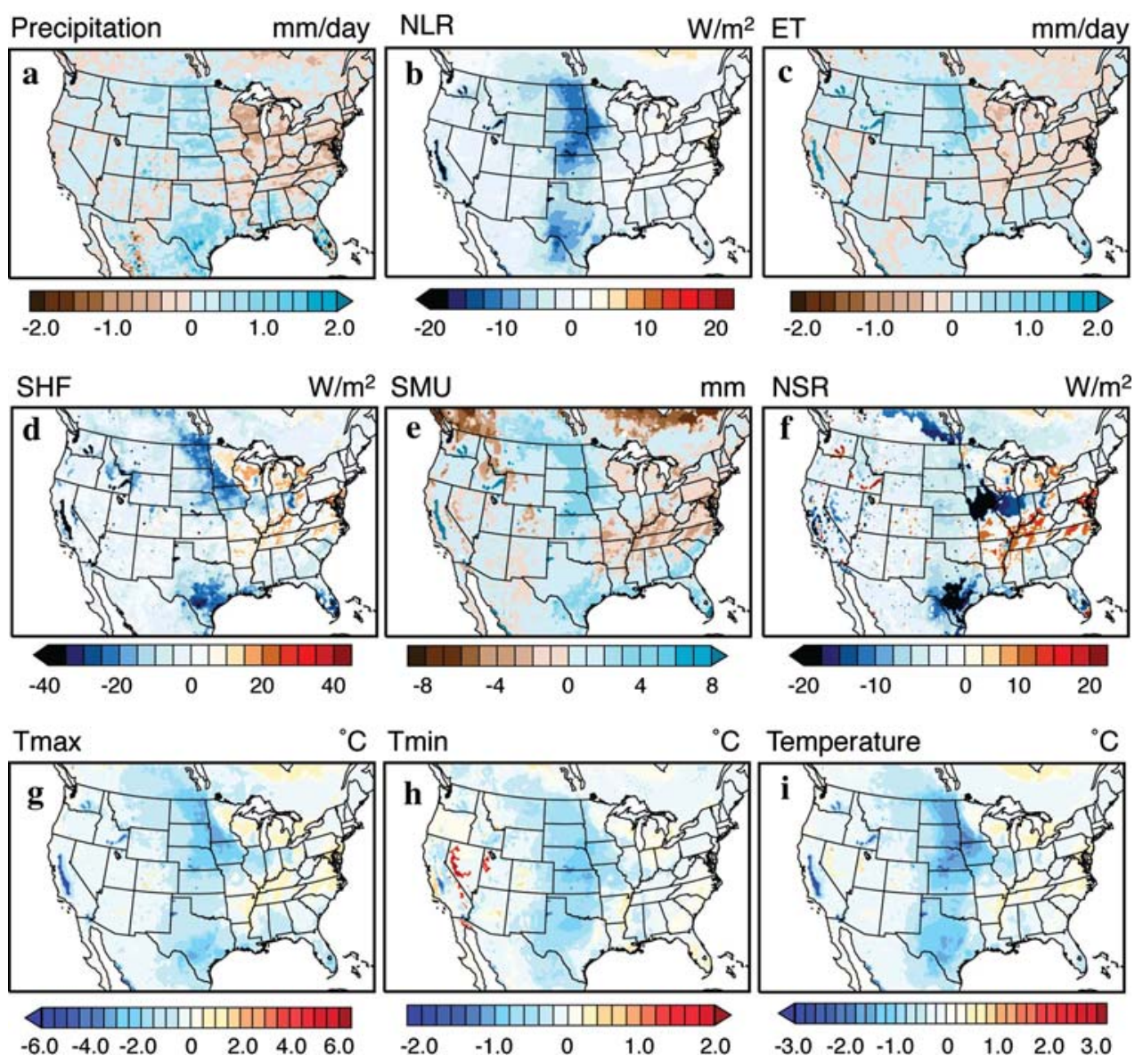

dataset) (Fig. 7). The climate model simulations both reproduce the basic time evolution of United States surface air temperature anomalies (Fig. 7). Further, when analyzing only those grid points for which land cover is different between the modern and preindustrial datasets (Fig. 1b), the time evolution of annual temperature anomalies is similar in both climate model simulations when expressed as a difference from the respective long-term mean of each dataset, whether for areas designated as crop and mixed farming, as irrigated crop, or as other non-crop types (Fig. 7).

In addition, the spatial pattern of annual temperature trends is similar between the two simulations (Fig. 8). The primary differences are in the eastern half of the United States, where the trends in the GLCC simulation are less positive than those in the RF simulation, including up to $-0.7 \mathrm{~K} /$ decade in mean surface air temperature, up to $-0.9 \mathrm{~K} /$ decade in mean daily maximum temperature, and up to $-0.4 \mathrm{~K} /$ decade in mean daily minimum temperature. The GLCC trends are more strongly positive than the RF trends over central Texas and much of Arizona, New Mexico, and northern Mexico.

\section{Discussion}

4.1 Mechanisms of climate response to land cover change

The dominant climate response to the modern non-urban land cover distribution is cooling of the continental United States, particularly during the warm-season. This statistically significant cooling is driven by changes in both surface moisture balance and surface albedo. For instance, in the Great Plains, where crops were exchanged for short grass, spring and summer display increased precipitation and soil moisture in the GLCC simulation (Figs. 3, 4). As a result of this enahanced surface moisture, these areas also display enhanced evapotranspiration, along with reduced sensible heat flux and cooler seasonal temperatures. This surface moisture effect is even stronger over the irrigated areas of the western United States that show statistically significant cooling (despite little change in warm-season precipitation), resulting in even larger cooling of surface air temperatures than in most other parts of the domain. The strength of this cooling in irrigated areas is likely 
Fig. 5 As in Fig. 2, but for autumn (SON)

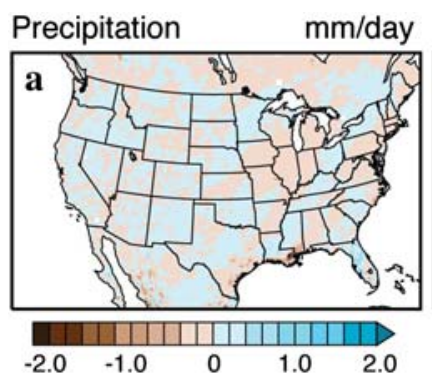

NLR

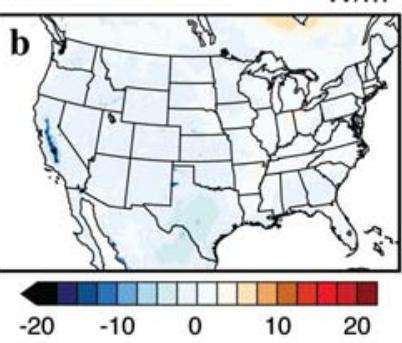

$\mathrm{W} / \mathrm{m}^{2} \mathrm{ET}$

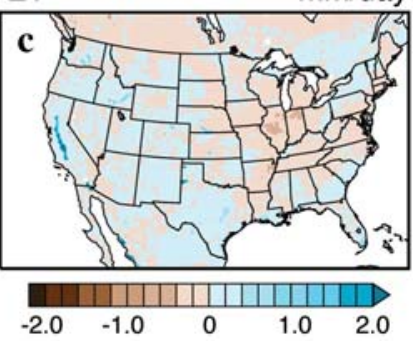

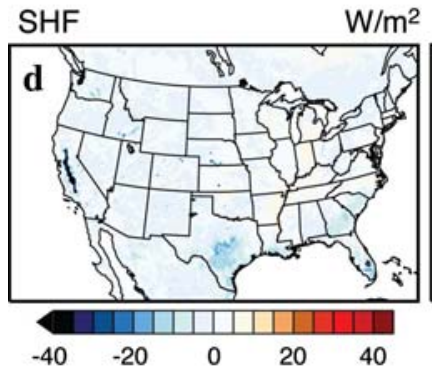
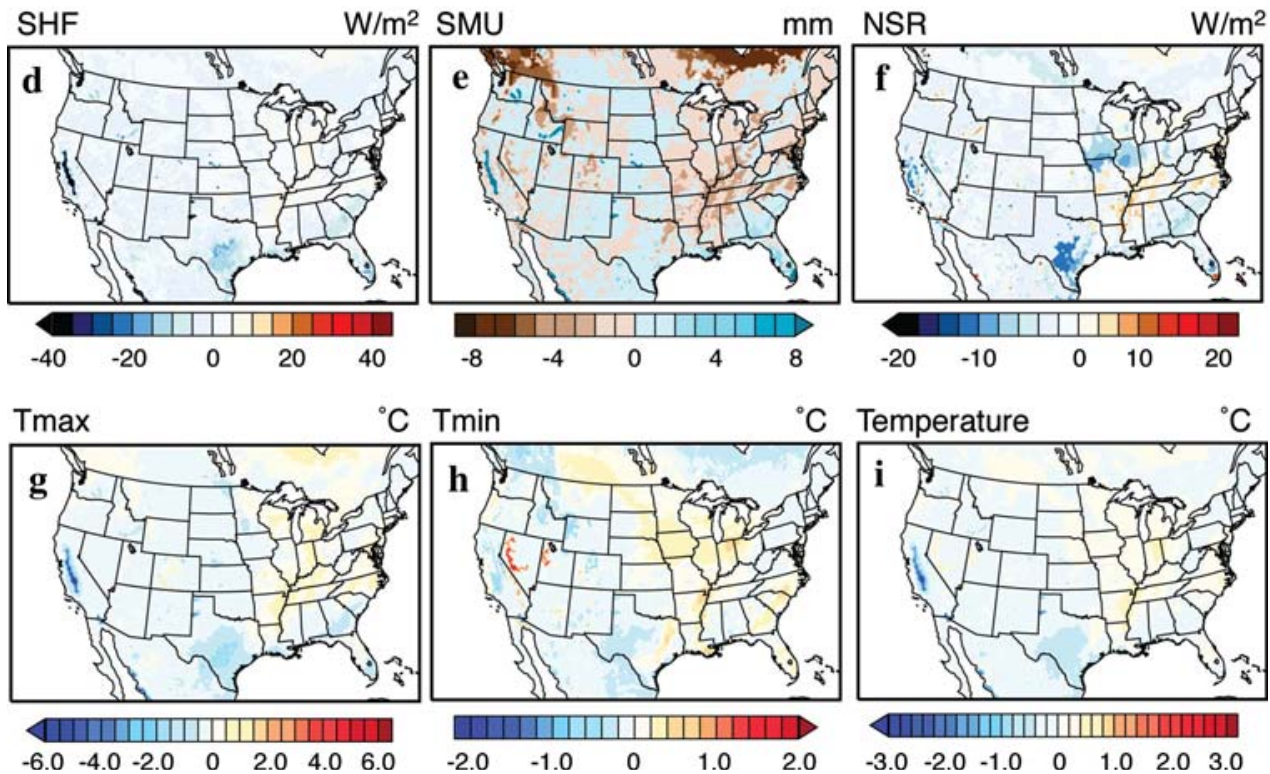

C Tmin
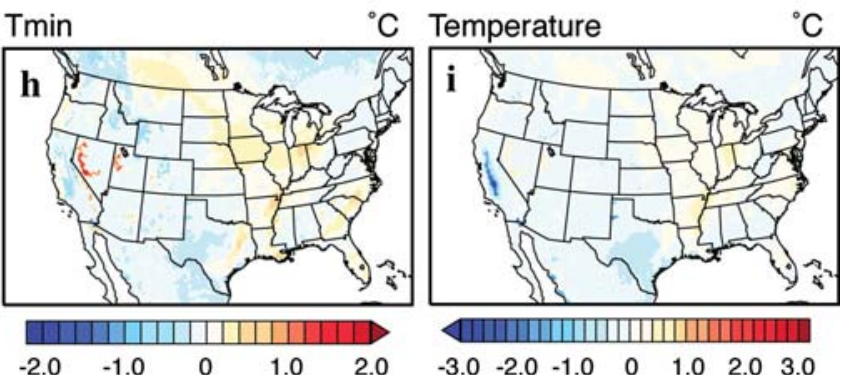

exaggerated by the BATS treatment that sets the soil moisture to field capacity throughout the year. Conversely, in the areas of the Midwest that show statistically significant warm-season temperature changes, increases in vegetation albedo contribute to decreases in net surface shortwave flux, overcoming decreases in evapotranspiration to create seasonal decreases in sensible heat flux and associated net cooling (Figs. 3, 4). Finally, changes in both surface moisture balance and surface albedo play a role in the temperature response in the areas of statistically significant warm-season cooling in southern Texas. In these areas, conversion of interrupted forest to crop/mixed farming leads to increases in surface soil moisture and evapotranspiration (along with increases in precipitation) (Figs. 3, 4). The conversion to crops also leads to increases in vegetation albedo (Fig. 11) that contributes to decreases in net surface shortwave flux. Thus, both the surface moisture effect and the surface albedo effect contribute to decreased warm-season sensible heat flux and seasonal cooling over southern Texas.

The changes in surface moisture and energy fluxes also influence the large-scale atmospheric dynamics. For instance, during the warm-season, the GLCC simulation exhibits enhanced atmospheric moisture content at $850 \mathrm{mb}$

over the central (spring and summer) and western (summer and autumn) United States (Fig. 9). Likewise, the GLCC simulation exhibits enhanced cyclonic circulation at $500 \mathrm{mb}$ over the southcentral (spring and summer), northcentral (summer and autumn), and southeastern (summer and autumn) United States (Fig. 10). These warm-season atmospheric moisture and circulation changes are particularly pronounced over the areas that show statistically significant warm-season temperature changes (Fig. 6). These atmospheric conditions tend to create greater moisture availability in the lower atmosphere along with enhanced uplift aloft, consistent with the enhanced precipitation seen in the GLCC simulation. Given that the large-scale boundary conditions are identical between the two nested climate model simulations, these simulated changes in atmospheric moisture and circulation suggest that land cover changes could "upscale" to influence largescale climate processes. Similar upscaling from land cover has been identified previously, including by (Chase et al. 2000), (Zhao et al. 2001) and (Werth and Avissar 2002), all of whom found remote responses to land cover change within a global climate modeling framework.

A number of previous studies report that crops cool the surface relative to the corresponding potential vegetation 
Fig. 6 Statistically significant changes in mean monthly daily maximum surface air temperature (top row), daily minimum surface air temperature (second row), mean surface air temperature (third row), and total precipitation (bottom row). Only those grid points for which changes (GLCC minus RF) are statistically significant at the 95\% confidence level are shown
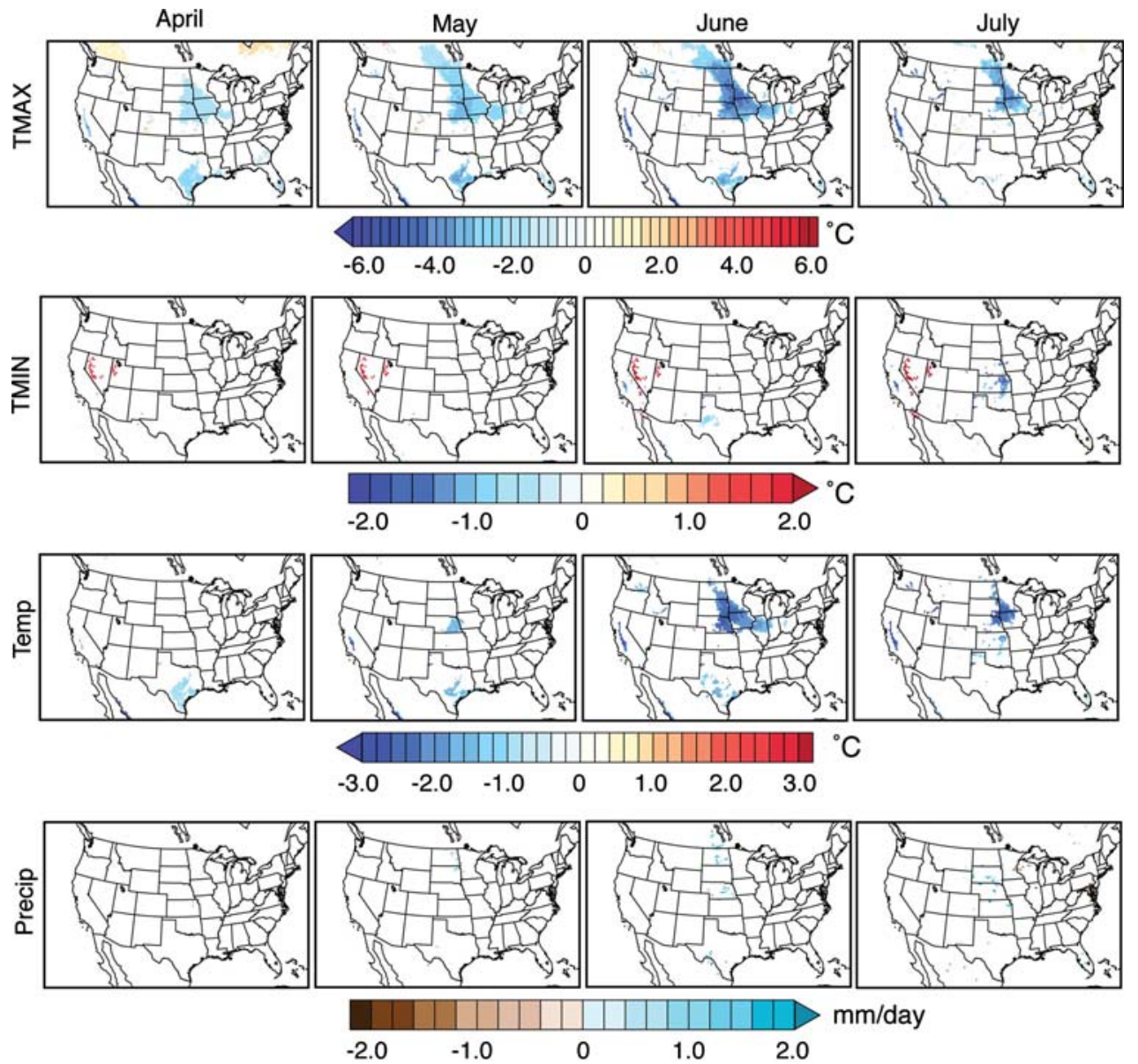

et al. 2006a), and irrigation in the Central Valley of California has been shown to cause local cooling in a number of climate models (Kueppers et al. 2007, 2008). Further, observed expansion of irrigation has been linked to observed cooling of summer daytime temperatures (Bonfils and Lobell 2007).

\subsection{Implications for observed temperature trends}

The large-scale expansion of agricultural areas from the late eighteenth century through the mid-twentieth century (Ramankutty and Foley 1999) could have influenced changes in global mean temperature by opposing the effects of rising greenhouse gas concentrations (e.g., Feddema et al. 2005a; Govindasamy et al. 2001). The climate model experiments presented here suggest that the transition of potential vegetation to the modern non-urban land cover distribution could have cooled the United States by $0.19^{\circ} \mathrm{C}$ annually. Therefore, if not for the expansion of agriculture, warming of the United States prior to the mid-twentieth century would have been even greater than what has been observed [e.g., $\sim 0.5^{\circ} \mathrm{C}$ between 1900 and 1950 (IPCC 2007)]. The results presented here integrate the 
Fig. 7 Mean United States temperature anomalies from 1988-2002. a The WillmottMatsuura global terrestrial air temperature timeseries

(Willmott and Matsuura 2001) (1988-1999) is shown in black, the CRU TS 2.0 dataset (Mitchell and Jones 2005) (1988-2000) is shown in green, and the North American Regional Reanalysis product (Mesinger et al. 2006) (19882002) is shown in yellow. The RegCM3 GLCC simulation is shown in blue, and the RegCM3 $\mathrm{RF}$ simulation is shown in red. For each dataset, annual values are shown as the departure in each year from the respective mean of that dataset's long-term timeseries (K). The slope of each timeseries is shown in Table 1. Area means are calculated over the area shown in Fig. 1. b Temperature anomaly for areas converted to crop and mixed farming. c Temperature anomaly for areas converted to irrigated crop. d Temperature anomaly for areas converted to non-crop types

Fig. 8 Linear temperature trends for the period 19882002. Mean surface air temperature (left column), daily maximum surface air temperature (center column) and daily minimum surface air temperature (right column) for the GLCC (top row) and RF (center row) simulations.

Differences (GLCC minus RF; bottom row)
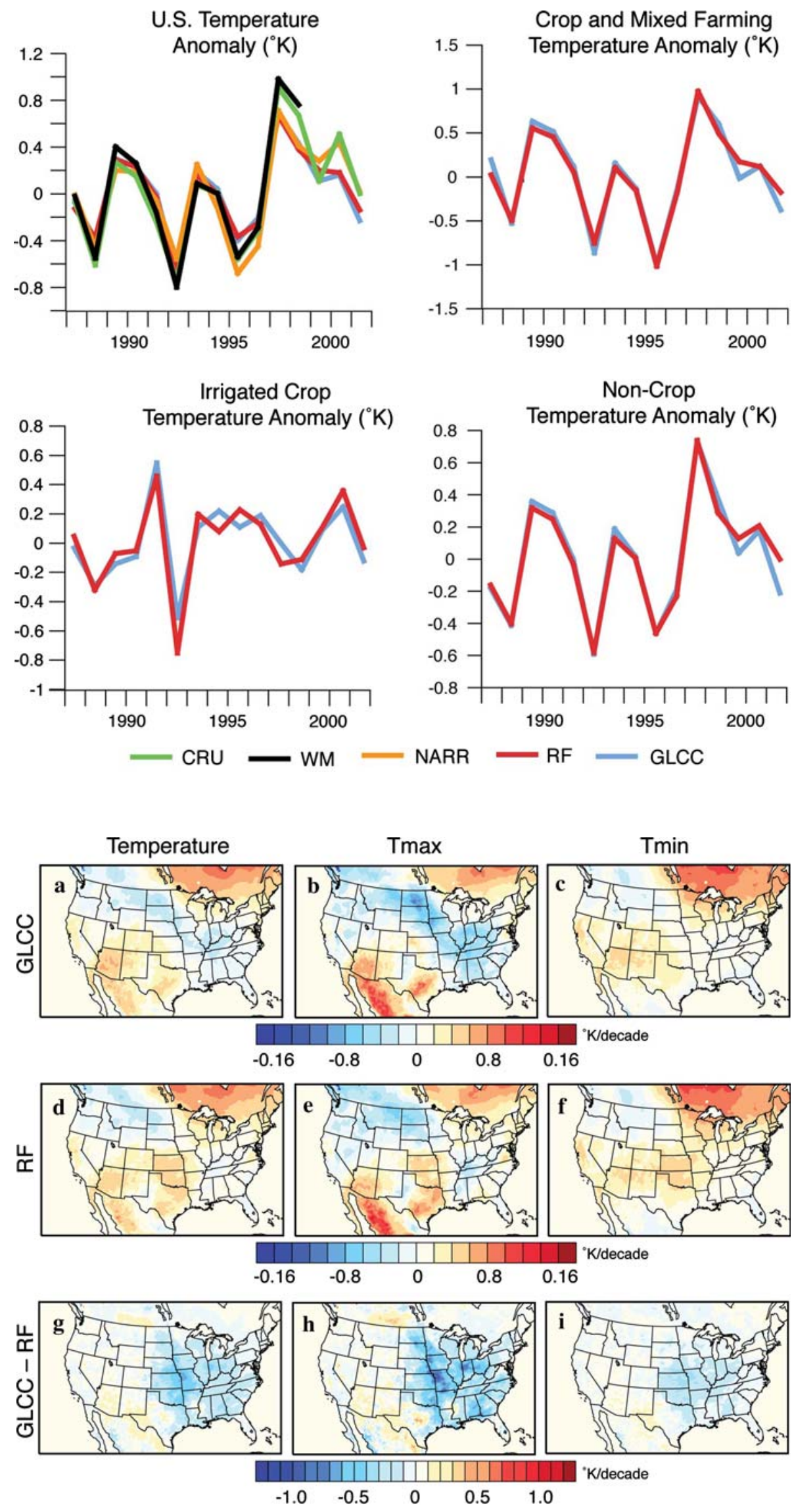
Fig. 9 Atmospheric circulation and moisture content. Differences (GLCC minus RF) in wind vectors and mixing ratio at $850 \mathrm{mb}$ for DJF (a), MAM (b), JJA (c), and SON (d)

Fig. 10 As in Fig. 9, but for $500 \mathrm{mb}$
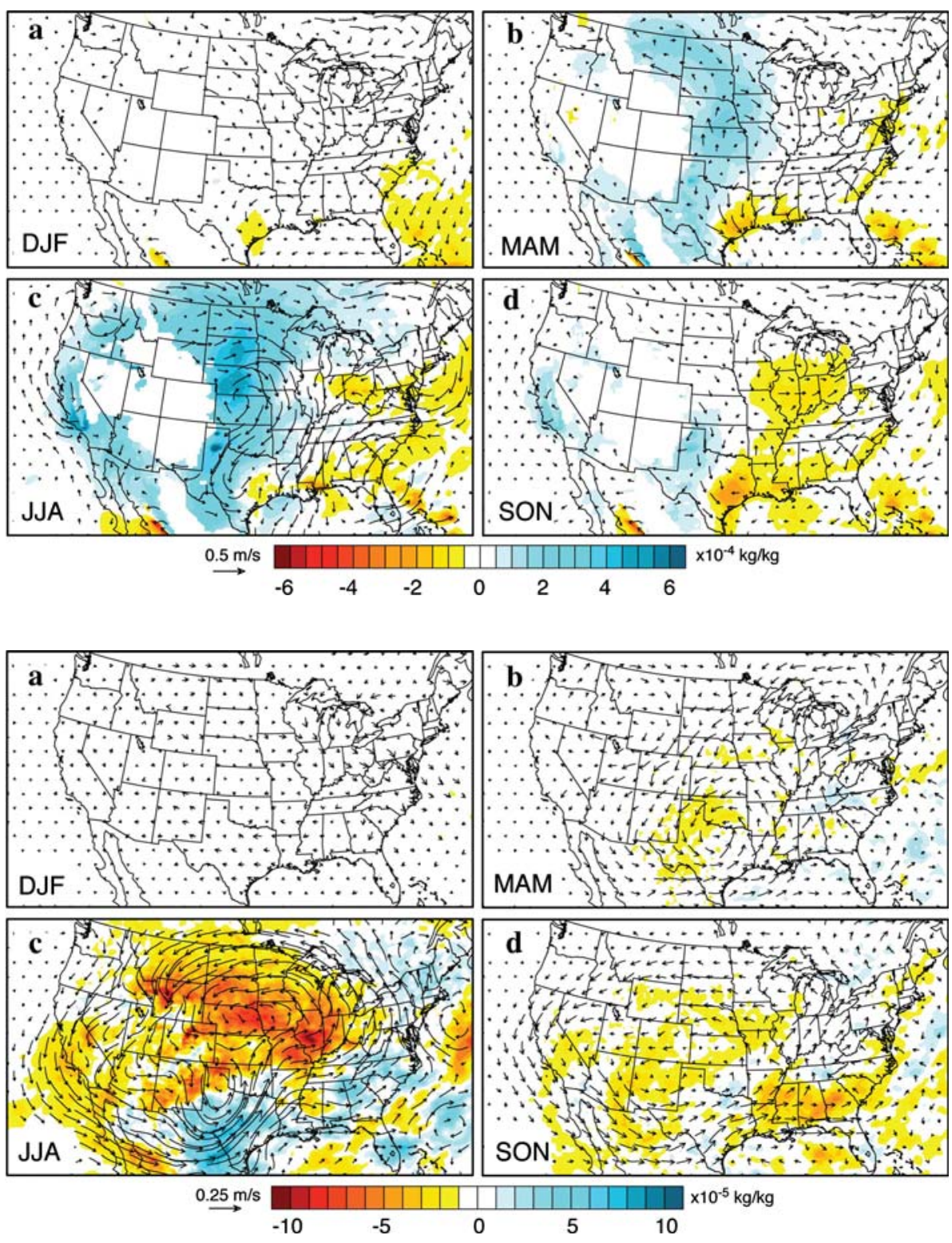

effects of land cover change in the United States with greater spatial detail (e.g., Bonan 1997; Govindasamy et al. 2001; Lobell et al. 2006a) or over a larger spatial area (Kueppers et al. 2007, 2008; Lamptey et al. 2005) than previous studies. This extension of the experimental framework reveals substantial spatial heterogeneity in both the temperature response and the dynamics governing that response (e.g., Figs. 4, 11), including changes in the largescale circulation (Figs. 9, 10).

The results presented here also give some indication that the presence of crop areas could have influenced the trend in surface air temperature over the late twentieth century period. Not only is the United States annual temperature trend more positive in the simulation without crops (RF) than in the simulation with crops (GLCC), but replacement of crop areas with potential vegetation reduces the slope of temperature change in those areas (Table 1). However, these trend differences are relatively small. Further, replacement of crop areas with potential vegetation has limited effect on the time evolution of annual temperature anomalies at those gridpoints (expressed as a difference from the respective long-term mean of each dataset) (Fig. 7). Based on these results, the influence of crop presence on recent United States surface air temperature is equivocal.

However, it should be noted that agricultural practices can influence surface climate (e.g., Lobell et al. 2006b), and changes in practice could therefore have influenced late twentieth century temperature trends independent of changes in crop distribution. Further, the experiments reported here did not include urban land cover. The trend in annual temperature for the United States domain is greater 
Longwave albedo

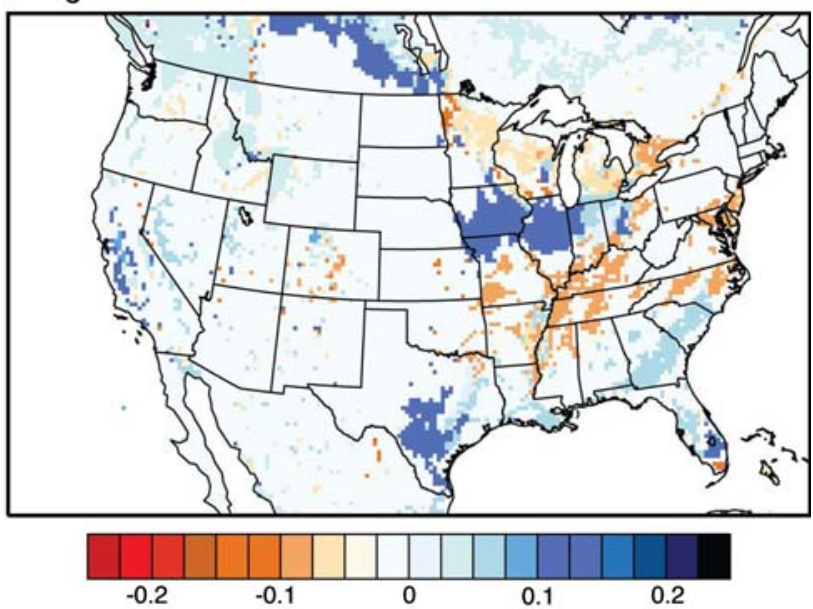

Shortwave albedo

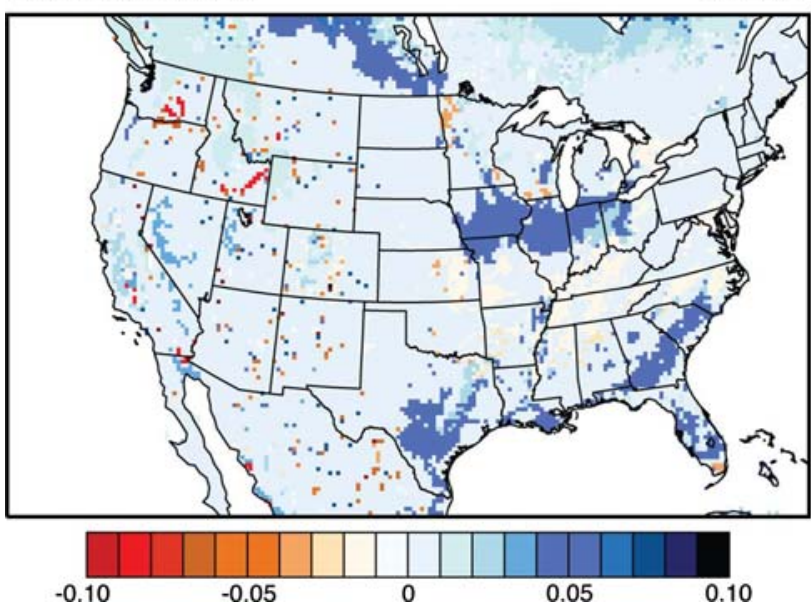

Fig. 11 Differences in vegetation albedo between the GLCC and RF land cover prescriptions (GLCC minus RF). a Longwave $(>0.7 \mu \mathrm{m})$ albedo. b Shortwave $(<0.7 \mu \mathrm{m})$ albedo

in the Climate Research Unit and Willmott-Matsuura datasets than in either the RF or GLCC simulation (Table 1). Both of those station-based datasets reflect the influence of expanded urban areas on surface temperature trends, indicating that the absence of urban areas in the climate model experiments could have damped the warming simulated over the 1988-2002 period.

\subsection{Implications for future land cover changes}

The results presented here suggest that future changes in land use could substantially affect climate by altering biophysical land-atmosphere interactions. Indeed, the changes in warm-season precipitation and evapotranspiration are similar in magnitude to those projected from high-resolution simulations of late-twenty-first century greenhouse gas forcing in the United States (e.g., Diffenbaugh et al. 2005), while the changes in warm-season temperature are similar in magnitude to those projected from high-resolution simulations of mid-twenty-first century greenhouse gas forcing (e.g., Pan et al. 2004). Land use change should therefore be considered along with greenhouse gas forcing when planning for-or attempting to avoid-potential long-term changes in local and regional climate.

Indeed, the effort to reduce greenhouse gas-induced climate change could itself affect local and regional climate. Mitigation efforts are creating economic pressures that could cause land cover change, both through incentives to sequester carbon on land, and through incentives to reduce fossil carbon emissions through combustion of biofuels. The experiments reported here suggest that if economic incentives cause forest plantations to replace traditional crops (as in the economic modeling of Jackson et al. 2005), those carbon sequestration efforts could result in local and regional warming at mid-latitudes, particularly during the warm-season. Conversely, should economic incentives cause crop-based biofuel production to replace forests, those land cover conversions could result in local and regional cooling at mid-latitudes. One major source of uncertainty is the extent to which regional irrigation would change along with those land cover conversions, especially given changes in plant water use efficiency at high atmospheric carbon dioxide concentrations (e.g., Diffenbaugh 2005a; Diffenbaugh et al. 2003).

Efforts to specifically quantify the effects of carbon sequestration on surface climate are mixed. On the one hand, several studies suggest that enhanced sequestration will cause local and regional warming in the extratropics by reducing surface albedo (e.g., Bala et al. 2006, 2007; Betts 2000; Betts et al. 2007; Diffenbaugh 2005a). On the other hand, Jackson et al. 2005 found that, in repeated simulations of the month of July, replacement of crops with forest plantations in the eastern United States increased evapotranspiration and decreased surface air temperature.

\section{Conclusions}

I have tested the sensitivity of regional and local climate to the modern non-urban land cover distribution of the continental United States. This high-resolution climate model experiment reveals that crop areas cause substantial cooling over large areas of the country. Areas of statistically significant cooling include areas of the Great Plains where crop/mixed farming has replaced short grass, areas of the Midwest and southern Texas where crop/mixed farming has replaced interrupted forest, and areas of the western United States containing irrigated crops. This statistically significant warm-season cooling is driven by changes in both surface moisture balance and surface albedo, with changes in surface moisture balance dominating in the 
Great Plains and western United States, changes in surface albedo dominating in the Midwest, and both effects contributing to warm-season cooling over southern Texas. In addition, the late twentieth century United States annual temperature trend is more positive in the simulation without crops than in the simulation with crops, but these trend differences are relatively small.

These results have important implications for future climate, energy, and land use policies. For instance, future conversion from crop to other land types could cause warming (particularly through urbanization (Kueppers et al. 2007)) and afforestation for carbon sequestration (e.g., Diffenbaugh 2005a; Jackson et al. 2008), while future expansion of crop area could cause cooling (particularly through expansion into marginal areas that require substantial irrigation). Further, in addition to direct influences on climate, the presence of agriculture could suppress regional and local warming at high greenhouse gas levels (Diffenbaugh et al. 2005; White et al. 2006), meaning that there could be secondary climatic effects of transitioning crops to forests as greenhouse gas concentrations continue to rise. The results presented here therefore suggest that the climatic effects of land cover change should be carefully considered when crafting policies for regulating land use and for managing anthropogenic forcing of the climate system.

Acknowledgments I thank two anonymous reviewers for constructive and insightful insights. NCEP-DOE Reanalysis data provided by the NOAA-CIRES Climate Diagnostics Center, Boulder, Colorado, USA, from their website at http://www.cdc.noaa.gov/. This work was supported in part by NSF awards 0315677 and 0450221 , and DOE award DE-FG02-08ER64649. The climate model simulations and analyses were carried out using computational resources in the Rosen Center for Advanced Computing (RCAC) at Purdue University, which is supported and administered by Information Technology at Purdue (ITaP). This is PCCRC paper number 0708.

Open Access This article is distributed under the terms of the Creative Commons Attribution Noncommercial License which permits any noncommercial use, distribution, and reproduction in any medium, provided the original author(s) and source are credited.

\section{References}

Bala G, Caldeira K, Mirin A, Wickett M, Delire C, Phillips TJ (2006) Biogeophysical effects of $\mathrm{CO}_{2}$ fertilization on global climate. Tellus B Chem Phys Meteorol 58:620-627. doi:10.1111/j.16000889.2006.00210.x

Bala G, Caldeira K, Wickett M, Phillips TJ, Lobell DB, Delire C, Mirin A (2007) Combined climate and carbon-cycle effects of large-scale deforestation. Proc Natl Acad Sci USA 104:65506555. doi: $10.1073 /$ pnas.0608998104

Betts RA (2000) Offset of the potential carbon sink from boreal forestation by decreases in surface albedo. Nature 408:187-190. doi: $10.1038 / 35041545$
Betts RA, Falloon PD, Goldewijk KK, Ramankutty N (2007) Biogeophysical effects of land use on climate: model simulations of radiative forcing and large-scale temperature change. Agric For Meteorol 142:216-233. doi:10.1016/j.agrformet.2006.08.021

Bonan GB (1997) Effects of land use on the climate of the United States. Clim Change 37:449-486. doi:10.1023/A:1005305708775

Bonan GB (1999) Frost followed the plow: impacts of deforestation on the climate of the United States. Ecol Appl 9:1305-1315. doi: 10.1890/1051-0761(1999)009[1305:FFTPIO]2.0.CO;2

Bonan GB (2001) Observational evidence for reduction of daily maximum temperature by croplands in the Midwest United States. J Clim 14:2430-2442. doi:10.1175/1520-0442(2001)014 $<2430$ :OEFROD $>2.0 . \mathrm{CO} ; 2$

Bonfils C, Lobell D (2007) Empirical evidence for a recent slowdown in irrigation-induced cooling. Proc Natl Acad Sci USA 104:13582-13587. doi:10.1073/pnas.0700144104

Bounoua L, Defries R, Collatz GJ, Sellers P, Khan H (2002) Effects of land cover conversion on surface climate. Clim Change 52:29-64. doi:10.1023/A:1013051420309

Brazel A, Gober P, Lee SJ, Grossman-Clarke S, Zehnder J, Hedquist B, Comparri E (2007) Determinants of changes in the regional urban heat island in metropolitan Phoenix (Arizona, USA) between 1990 and 2004. Clim Res 33:171-182. doi:10.3354/ cr033171

Changnon SA (2001) Assessment of historical thunderstorm data for urban effects: the Chicago case. Clim Change 49:161-169. doi: 10.1023/A:1010797013336

Chase TN, Pielke RA, Kittel TGF, Nemani RR, Running SW (2000) Simulated impacts of historical land cover changes on global climate in northern winter. Clim Dyn 16:93-105. doi:10.1007/ s003820050007

Christy JR, Norris WB, Redmond K, Gallo KP (2006) Methodology and results of calculating central California surface temperature trends: evidence of human-induced climate change? J Clim 19:548-563. doi:10.1175/JCLI3627.1

Dickinson RE, Henderson-Sellers A, Kennedy PJ (1993) BiosphereAtmosphere Transfer Scheme (BATS) version 1e as coupled to the NCAR community climate model. National Center for Atmospheric Research, Boulder

Diffenbaugh NS (2005a) Atmosphere-land cover feedbacks alter the response of surface temperature to $\mathrm{CO}_{2}$ forcing in the western United States. Clim Dyn 24:237-251. doi:10.1007/s00382004-0503-0

Diffenbaugh NS (2005b) Sensitivity of extreme climate events to $\mathrm{CO}_{2}$-induced biophysical atmosphere-vegetation feedbacks in the western United States. Geophys Res Lett 32:L07702. doi: 10.1029/2004GL022184

Diffenbaugh NS, Sloan LC (2002) Global climate sensitivity to land surface change: the Mid Holocene revisited. Geophys Res Lett 29:1476. doi:10.1029/2002GL014880

Diffenbaugh NS, Sloan LC, Snyder MA, Bell JL, Kaplan JO, Shafer SL, Bartlein PJ (2003) Vegetation sensitivity to global anthropogenic carbon dioxide emissions in a topographically complex region. Global Biogeochem Cycles 17:1067. doi:10.1029/ 2002GB001974

Diffenbaugh NS, Pal JS, Trapp RJ, Giorgi F (2005) Fine-scale processes regulate the response of extreme events to global climate change. Proc Natl Acad Sci USA 102:15774-15778. doi: 10.1073/pnas.0506042102

Diffenbaugh NS, Ashfaq M, Shuman B, Williams JW, Bartlein PJ (2006) Summer aridity in the United States: response to midHolocene changes in insolation and sea surface temperature. Geophys Res Lett 33:L22712. doi:10.1029/2006GL028012

Fargione J, Hill J, Tilman D, Polasky S, Hawthorne P (2008) Land clearing and the biofuel carbon debt. Science 319:1235-1238. doi: $10.1126 /$ science. 1152747 
Feddema J, Oleson K, Bonan G, Mearns L, Washington W, Meehl G, Nychka D (2005a) A comparison of a GCM response to historical anthropogenic land cover change and model sensitivity to uncertainty in present-day land cover representations. Clim Dyn 25:581-609. doi:10.1007/s00382-005-0038-z

Feddema JJ, Oleson KW, Bonan GB, Mearns LO, Buja LE, Meehl GA, Washington WM (2005b) The importance of land-cover change in simulating future climates. Science 310:1674-1678. doi:10.1126/science. 1118160

Foley JA, Kutzbach JE, Coe MT, Levis S (1994) Feedbacks between climate and boreal forests during the Holocene epoch. Nature V371:52-54. doi:10.1038/371052a0

Fritsch JM, Chappell CF (1980) Numerical prediction of convectively driven mesoscale pressure systems. Part I: convective parameterization. J Atmos Sci 37:1722-1733. doi:10.1175/1520-0469 (1980)037<1722:NPOCDM >2.0.CO;2

Govindasamy B, Duffy PB, Caldeira K (2001) Land use changes and Northern Hemisphere cooling. Geophys Res Lett 28:291-294. doi:10.1029/2000GL006121

Grell GA (1993) Prognostic evaluation of assumptions used by cumulus parameterizations. Mon Weather Rev 121:764-787. doi:10.1175/1520-0493(1993)121<0764:PEOAUB > 2.0.CO;2

Grell GA, Dudhia J, Stauffer DR (1994) Description of the fifth generation Penn State/NCAR Mesoscale Model (MM5), Technical Report TN-398 + STR. National Center for Atmospheric Research, Boulder

Haxeltine A, Prentice IC (1996) BIOME3: an equilibrium terrestrial biosphere model based on ecophysiological constraints, resource availability, and competition among plant functional types. Global Biogeochem Cycles 10:693-709. doi:10.1029/96GB02344

Holtslag AAM, De Bruijn EIF, Pan HL (1990) A high resolution air mass transformation model for short-range weather forecasting. Mon Weather Rev 118:1561-1575. doi:10.1175/1520-0493 (1990)118<1561:AHRAMT>2.0.CO;2

IPCC (2007) Climate change 2007: the physical science basis. In: Solomon S, Qin D, Manning M, Chen Z, Marquis M, Averyt KB, Tignor M, Miller HL (eds) Contribution of working group I to the fourth assessment report of the intergovernmental panel on climate change. Cambridge University Press, Cambridge, 996 pp

Jackson RB, Jobbagy EG, Avissar R, Roy SB, Barrett DJ, Cook CW, Farley KA, Le Maitre DC, Mccarl BA, Murray BC (2005) Trading water for carbon with biological sequestration. Science 310:1944-1947. doi:10.1126/science.1119282

Jackson RB, Randerson JT, Canadell JG, Anderson RG, Baldocchi DD, Bonan GB, Caldeira K, Diffenbaugh NS, Field CB, Hungate BA, Jobbagy EG, Kueppers LM, Nosetto MD, Pataki DE (2008) Protecting climate with forests. Environ Res Lett 3:044006. doi: 10.1088/1748-9326/3/4/044006

Kalnay E, Cai M (2003) Impact of urbanization and land-use change on climate. Nature 423:528-531. doi:10.1038/nature01675

Kanamitsu M, Ebisuzaki W, Woollen J, Yang SK, Hnilo JJ, Fiorino M, Potter GL (2002) NCEP-DOE AMIP-II Reanalysis (R-2). Bull Am Meteorol Soc 83:1631-1643. doi:10.1175/BAMS-8311-1631(2002)083<1631:NAR > 2.3.CO;2

Kiehl JT, Hack JJ, Bonan GB, Boville BA, Briegleb BP, Williamson DL, Rasch PJ (1996) Description of the NCAR Community Climate Model (CCM3), Technical Report TN-420 + STR. National Center for Atmospheric Research, Boulder

Kueppers LM, Snyder MA, Sloan LC (2007) Irrigation cooling effect: regional climate forcing by land-use change. Geophys Res Lett 34:L03703. doi:10.1029/2006GL028679

Kueppers LM, Snyder MA, Sloan LC, Cayan D, Jin J, Kanamaru H, Kanamitsu M, Miller NL, Tyree M, Due H, Weare B (2008) Seasonal temperature responses to land-use change in the western United States. Glob Planet Change 60:250-264. doi: 10.1016/j.gloplacha.2007.03.005
Lamptey BL, Barron EJ, Pollard D (2005) Impacts of agriculture and urbanization on the climate of the Northeastern United States. Glob Planet Change 49:203-221. doi:10.1016/j.gloplacha. 2005.10.001

Lobell DB, Bala G, Bonfils C, Duffy PB (2006a) Potential bias of model projected greenhouse warming in irrigated regions. Geophys Res Lett 33:L13709. doi:10.1029/2006GL026770

Lobell DB, Bala G, Duffy PB (2006b) Biogeophysical impacts of cropland management changes on climate. Geophys Res Lett 33:L06708. doi:10.1029/2005GL025492

Loveland TR, Reed BC, Brown JF, Ohlen DO, Zhu Z, Yang L, Merchant JW (2000) Development of a global land cover characteristics database and IGBP DISCover from $1 \mathrm{~km} \mathrm{AV}$ HRR data. Int J Remote Sens 21:1303-1330. doi:10.1080/ 014311600210191

Mears CA, Wentz FJ (2005) The effect of diurnal correction on satellite-derived lower tropospheric temperature. Science 309:1548-1551. doi:10.1126/science. 1114772

Mesinger F, Dimego G, Kalnay E, Mitchell K, Shafran PC, Ebisuzaki W, Jovic D, Woollen J, Rogers E, Berbery EH, Ek MB, Fan Y, Grumbine R, Higgins W, Li H, Lin Y, Manikin G, Parrish D, Shi W (2006) North American regional reanalysis. Bull Am Meteorol Soc 87:343. doi:10.1175/BAMS-87-3-343

Mitchell TD, Jones PD (2005) An improved method of constructing a database of monthly climate observations and associated highresolution grids. Int $\mathrm{J}$ Climatol 25:693-712. doi:10.1002/ joc. 1181

Oleson KW, Bonan GB, Levis S, Vertenstein M (2004) Effects of land use change on North American climate: impact of surface datasets and model biogeophysics. Clim Dyn 23:117-132. doi: 10.1007/s00382-004-0426-9

Pal JS, Small EE, Eltahir EAB (2000) Simulation of regional-scale water and energy budgets: representation of subgrid cloud and precipitation processes within RegCM. J Geophys Res 105:29579-29594. doi:10.1029/2000JD900415

Pal JS, Giorgi F, Bi X, Elguindi N, Solmon F, Gao X, Rauscher SA, Francisco R, Zakey A, Winter J, Ashfaq M, Syed FS, Bell JL, Diffenbaugh NS, Karmacharya J, Konare A, Martinez D, Da Rocha RP, Sloan LC, Steiner A (2007) Regional climate modeling for the developing world: the ICTP RegCM3 and RegCNET. Bull Am Meteorol Soc 89:1395-1409. doi:10.1175/ BAMS-88-9-1395

Pan ZT, Arritt RW, Takle ES, Gutowski WJ, Anderson CJ, Segal M (2004) Altered hydrologic feedback in a warming climate introduces a "warming hole". Geophys Res Lett 31:L17109. doi:10.1029/2004GL020528

Pielke RA, Marland G, Betts RA, Chase TN, Eastman JL, Niles JO, Niyogi DDS, Running SW (2002) The influence of land-use change and landscape dynamics on the climate system: relevance to climate-change policy beyond the radiative effect of greenhouse gases. Philos Trans R Soc Lond A Math Phys Eng Sci 360:1705-1719

Pitman AJ, Narisma GT, Pielke RA, Holbrook NJ (2004) Impact of land cover change on the climate of southwest Western Australia. J Geophys Res 109: D18109

Ramankutty N, Foley JA (1999) Estimating historical changes in global land cover: croplands from 1700 to 1992. Global Biogeochem Cycles 13:997-1027. doi:10.1029/1999GB900046

Ramankutty N, Delire C, Snyder P (2006) Feedbacks between agriculture and climate: an illustration of the potential unintended consequences of human land use activities. Glob Planet Change 54:79-93. doi:10.1016/j.gloplacha.2005.10.005

Santer BD, Thorne PW, Haimberger L, Taylor KE, Wigley TML, Lanzante JR, Solomon S, Free M, Gleckler PJ, Jones PD, Karl TR, Klein SA, Mears C, Nychka D, Schmidt GA, Sherwood SC, Wentz FJ (2008) Consistency of modelled and observed 
temperature trends in the tropical troposphere. Int $\mathrm{J}$ Climatol 28:1703-1722. doi:10.1002/joc. 1756

Schlesinger ME, Malyshev S (2001) Changes in near-surface temperature and sea-level for the Post-SRES CO2-stabilization scenarios. Integrated Assess 2:95-199. doi:10.1023/A:1013392915078

Searchinger T, Heimlich R, Houghton RA, Dong FX, Elobeid A, Fabiosa J, Tokgoz S, Hayes D, Yu TH (2008) Use of US croplands for biofuels increases greenhouse gases through emissions from land-use change. Science 319:1238-1240. doi: 10.1126/science. 1151861

Sherwood SC, Lanzante JR, Meyer CL (2005) Radiosonde daytime biases and late-20th century warming. Science 309:1556-1559. doi:10.1126/science. 1115640

Werth D, Avissar R (2002) The local and global effects of Amazon deforestation. J Geophys Res 107 (D20): 8087

White MA, Diffenbaugh NS, Jones GV, Pal JS, Giorgi F (2006) Extreme heat reduces and shifts United States premium wine production in the 21st century. Proc Natl Acad Sci USA 103:11217-11222. doi:10.1073/pnas.0603230103
Willmott CJ, Matsuura K (2001) Terrestrial air temperature and precipitation: monthly and annual time series (1950-1999). University of Delaware, Newark, http://climate.geog.udel.edu/ climate/html_pages/air_ts2.html

Wyputta U, Mcavaney BJ (2001) Influence of vegetation changes during the Last Glacial Maximum using the BMRC atmospheric general circulation model. Clim Dyn 17:923-932. doi: 10.1007/s003820100155

Yang ZL, Dickinson RE, Henderson-Sellers A, Pitman AJ (1995) Preliminary study of spin-up processes in land surface models with the first stage data of project for intercomparison of land surface parameterization schemes phase 1(a). J Geophys Res V100:16553-16578. doi:10.1029/95JD01076

Zhao M, Pitman AJ, Chase T (2001) The impact of land cover change on the atmospheric circulation. Clim Dyn V17:467-477. doi: 10.1007/PL00013740 